\title{
Are patents with multiple inventors from different countries a good indicator of international R\&D collaboration? The case of ABB
}

Anna Bergek and Bruzelius Maria

\section{Linköping University Post Print}

\section{Tweet}

N.B.: When citing this work, cite the original article.

Original Publication:

Anna Bergek and Bruzelius Maria, Are patents with multiple inventors from different countries a good indicator of international R\&D collaboration? The case of ABB, 2010, Research Policy, (39), 1321-1334.

http://dx.doi.org/10.1016/j.respol.2010.08.002

Copyright: Elsevier http://www.elsevier.com/

Postprint available at: Linköping University Electronic Press http://urn.kb.se/resolve?urn=urn:nbn:se:liu:diva-62574 


\title{
Are patents with multiple inventors from different countries a good indicator of international $R \& D$ collaboration? The case of ABB
}

\author{
Anna Bergek ${ }^{1}$ and Maria Bruzelius ${ }^{2}$ \\ Department of Management and Engineering \\ Linköping University \\ SE-581 83 Linköping \\ Sweden \\ Phone: +46-13-28 2573 \\ Fax: +46-13-28 1101 \\ E-mail: anna.bergek@liu.se
}

\begin{abstract}
Based on the critical case of $\mathrm{ABB}$, this paper questions the relevance of using patents with multiple inventors from different countries (“cross-country patents”) as an indicator of international R\&D collaboration. The study shows that less than half of ABB's cross-country patents are the result of international $R \& D$ collaboration as described by one of the more inclusive definitions found in previous literature. Only a third of the patents are the result of joint R\&D activities between different MNC subsidiaries or firms. We also discuss the implications of our study for the assignment of patents to countries based on inventor addresses.
\end{abstract}

Keywords: Patent data, R\&D collaboration, Cross-country patents

\footnotetext{
${ }^{1}$ Corresponding author

${ }^{2}$ Present address: Metrima Energi AB, Box 15039, SE-580 15 Linköping, Sweden.
} 


\section{Introduction}

The internationalization of $R \& D$ and technological activity has been described as a "key constituent of the globalization of trade and business, with potentially major impacts on patterns of economic development and public policies worldwide” (Meyer-Krahmer and Reger, 1999, p. 752). It is, thus, not surprising either that there is a large number of scientific studies of this process, or that several of these studies have found evidence of an increasing internationalization of technological activity (primarily R\&D) by multinational corporations (MNCs) (cf. Archibugi and Coco, 2001; Gassman and von Zedtwitz, 1999; Gerybadze and Reger, 1999; OECD, 2004; Patel, 1995; Patel and Vega, 1999).

Technological internationalization by MNCs may come in a variety of different forms: international exploitation of technology produced on a national basis, global technological collaborations and global generation of innovations by MNCs (cf., e.g., Archibugi and Michie, 1995). In this paper, we are primarily concerned with R\&D collaboration involving either cross-border projects within the internal R\&D networks of individual MNCs or projects involving MNCs and firms in other countries.

Both these forms have been studied empirically using patent data as an indicator of collaborative technological activity. In particular, the apparently 'inherent' international and collaborative nature of patents with multiple inventors from more than one country (from here on named 'cross-country patents') has caught the attention of a number researchers, who argue that they can be used as an indicator of international R\&D collaboration. That patents with multiple inventors is an indicator of collaboration is argued by, for example, Ma and Lee (2008, p. 382) who state that “... the presence of multiple inventors is a clear indicator of collaborative inventive activities” and by Carayol and Roux (2007, p. 278) who claim that when two people appear as inventors of the same patents, it "reveals a strong and deliberate collaboration between two persons.” With reference to the more specific issue of international R\&D collaboration, Archambault (2002, p. 21) argue that the largest advantage of tabulating statistics for every country that participates in inventions is the ability to identify trends in international collaboration: “... calculating data for multiple addresses ... reveals the patterns of collaboration in technological development.” Similarly, according to 
Archibugi and Pianta (1996) international collaborations are revealed in the rapid growth of patents with inventors from different countries. Examples of studies applying this indicator include Guellec and van Pottelsberghe de la Potterie’s (2001) study of European Patent Office patents with several inventors residing in different countries, Yamin and Otto's (2004) investigation of the collective knowledge sharing of 20 MNCs in the biopharmaceutical industry (in which they counted the share of patents with inventors in more than one country), a study by Frost and Zhou (2005) of the R\&D copractice in the pharmaceutical and automotive sectors, Cincera et al.’s (2006) study of (among other things) international collaboration between Belgian inventors and inventors from other countries and Singh's (2008) study of cross-regional ties between inventors.

However, no evidence has been presented in the literature that cross-country patents are either truly international (i.e. the result of joint activity between inventors from different countries), or the result of real R\&D collaboration rather than of other kinds of (technological) activities. ${ }^{3}$ In light of this, the purpose of this paper is to examine the cross-country patents of one $\mathrm{MNC}(\mathrm{ABB})$ in order to answer the following questions:

(1) To what extent are ABB's cross-country patents international and what characterizes the cross-country patents that are not international? (2) To what extent are ABB's international cross-country patents the result of activities corresponding to the notion of $R \& D$ collaboration as described in previous literature and what is the origin of those patents that are not the result of R\&D collaboration? (3) What are the implications of this case study for the relevance of using cross-country patents as an indicator of R\&D collaboration?

The paper is structured as follows. In Section 2, we review previous work on international $\mathrm{R} \& \mathrm{D}$ collaboration in order to understand how the concept of international R\&D collaboration can be interpreted, and develop a scheme of analysis that will guide the empirical analysis. Section 3 provides a description of the case selection and data collection method used. In Section 4, we analyze the cross-country patents of ABB, and the activities underlying them, according to this scheme of analysis in order to answer

\footnotetext{
${ }^{3}$ Although Meyer and Bhattacharya (2004) discuss the relevance of applying co-authorship analysis to co-invented patents, they never question that they are the result of collaborative inventive efforts.
} 
questions outlined above. We show that a large share of ABB's cross-country patents is not truly international, but rather the result of some spurious features of the patent registration system. In particular, inventor movement creates many false cross-country patents. We also show that most of the international patents are not the result of R\&D collaboration as described in the literature. More specifically, a large share of these patents is the result of either intra-organizational interaction or non-R\&D activities. Finally, in Section 5 we sum up our conclusions. We argue that our study casts serious doubts on the relevance of using cross-country patents as an indicator of international R\&D collaboration. We also discuss the implications of our study for further research in more general terms; in particular we discuss the difference between established principles for assigning cross-country patents to countries for the purpose of identifying the location of inventive activities and give some recommendations to researchers with regards to this issue.

\section{Cross-country patents as an indicator of international $R \& D$ collaboration: literature review and scheme of analysis}

\section{$2.1 \quad$ Introduction}

The focus of this paper is international R\&D collaboration. In a general sense, the concept of 'collaboration' describes various situations when two or more partners (people or organizations) interact with each other to produce some kind of outcome. When R\&D collaboration is concerned, the focus is obviously on research and development activities. The word 'international' implies that more than one country is somehow involved. Although perhaps specific enough for more general discussions, this definition allows for a broad range of activities and organizational arrangements and does not reflect to a full extent the more specific definitions found in literature. In this section, we will, therefore, review the previous literature in order to qualify the concepts of 'international' and 'collaboration', by identifying different categories within each concept, describing the degree to which an activity is international and collaborative respectively. Based on this categorization, we will develop a scheme of analysis that will be applied in the empirical analysis in the next section. 


\subsection{What characterizes 'international’ $R \& D$ ?}

The internationalization of $R \& D$ is essentially about the distribution of $R \& D$ activities across national borders. What is meant by 'international' is, however, far from clear. In order to clarify the discussion of this topic, we take our departure in the three categories of globalization of innovation developed by Archibugi with colleagues: (1) the international exploitation of technology produced on a national basis, (2) global technological collaborations, i.e. agreements between firms for joint development and (3) the global generation of innovations by MNCs (Archibugi and Michie, 1995; Archibugi and Iammarino, 1999). Similar to this paper, the unit of analysis of this categorization is the innovation or project level (Archibugi and Iammarino, 1999).

Since the first category is concerned with exports of goods, licensing and production rather than with R\&D activities (cf. Archibugi and Iammarino, 1999, Table 1), we will focus the discussion on the second and third categories. The second category includes cases when two different firms, located in two or more countries, decide to establish a joint venture to develop technology (Archibugi and Pietrobelli, 2003). In relation to the definition of 'international', the focus of this category is thus the geographic dispersion of the participating companies between different countries. The third category (the global generation of innovation by MNCs), refers to innovation generated by single proprietors on a global scale (Archibugi and Pietrobelli, 2003). 'International' is here defined primarily in terms of the location of R\&D activities outside the home country of the company. For example, the empirical data presented by Archibugi and Iammarino (1999) concern innovation generated outside the home country of the parent companies and all the three strategies for global generation of technology discussed by Archibugi and Pietrobelli (2003) describe R\&D activities as primarily local in nature (either in home or host countries) rather than spanning national borders. ${ }^{4}$

Two main perspectives on how to define 'international' $R \& D$ activities thus emerges from this categorization: (a) R\&D activities distributed between multiple national locations and (b) R\&D activities located in a country other than the home country of the corporation. Research using the latter definition tends to be concerned with issues such

\footnotetext{
${ }^{4}$ The resulting technology is, however, commonly thought of as shared across the organisation (cf. Almeida and Phene, 2004).
} 
as development of typologies/taxonomies for internationally dispersed technology units (for an overview, see Medcof (1997)), corporate-level R\&D networks (e.g. Gassman and von Zedtwitz, 1999) and internationalization objectives (e.g. home-base exploiting vs. home-base augmenting; cf. Kuemmerle, 1999). This paper is, however, not about internationalization as such, but deals with the specific issue of international R\&D collaboration resulting in patents. This implies that we are not interested in how much of a company’s R\&D network is located outside the home country, which structural option it uses to organize this network on a corporate level or its motives for locating R\&D activities in foreign countries. Instead, the focus of the discussion is on how international $R \& D$ projects can be distinguished from non-international R\&D projects (and, later on in this section, how collaborative R\&D projects can be distinguished from non-collaborative R\&D projects). Following, e.g., Archibugi and Coco (2004), we will therefore define international $R \& D$ projects as projects involving participants located in more than one country.

Within this perspective, we may distinguish between projects involving inventors located (or residing) in different countries and organizational units (firms or MNC subsidiaries, see further below) located in different countries. Due to nature of the data we are studying, it might be reasonable to assume that we are primarily concerned with projects involving inventors from different countries. However, there are two problems with such a definition. First, although the literature tends to assume that inventors work in their country of residence (cf. Almeida and Phene, 2004; Cantwell and Piscitello, 2000; Frost, 2001; Guellec and van Pottelsberghe de la Potterie, 2001; Le Bas and Sierra, 2002; Patel and Vega, 1999; Zander, 1999), this is not always the case. For example, many people live and work in different countries. This implies that people that reside in different countries may very well work together every day in the same country. Categorizing projects involving such inventors as 'international' would dilute the concept far too much, we think. Second, collaborative R\&D projects may involve temporary co-location of personnel from the involved organizations (cf. Frost and Zhou, 2005; Howells, 1990). In such cases, inventors are located in the same geographical place during the projects, but since they represent different historical and cultural backgrounds, education systems, etc. (Grupp and Schmoch, 1999) it still seems relevant to categorize these projects as international. It, thus, seems necessary to combine the 
inventor and organization aspects. We therefore define 'international' $\mathrm{R} \& \mathrm{D}$ as involving multiple inventors normally working in organizational units located in different countries.

This definition is of a dichotomous nature - either R\&D activities involve multiple inventors normally working in different countries or not. However, some researchers argue that it may be fruitful to recognize that international $R \& D$ activities can be more or less international (cf. Bergek and Berggren, 2004; Kuemmerle, 1999; Guellec and van Pottelsberghe de la Potterie, 2001). A common distinction used in the literature is that between on the one hand 'international' $R \& D$ and on the other hand 'global' $R \& D$, where the latter (which is a subset of the former) indicates a broader dispersion of activities than the former (for example, across two or more regions/continents (cf. Georghiou, 1998; Medcof, 1997)). We will therefore complement our main analysis with an investigation of the more specific geographic dispersion of the $R \& D$ activities that we categorize as 'international' and discuss to what extent they can be considered 'global'. The methods used to assign patents to countries will be discussed further in Section $3 .^{5}$

\subsection{What characterizes 'collaborative’ $R \& D$ ?}

Collaboration can be defined as an activity where two or more partners make substantial contributions of resources and know-how to agreed aims (cf. Archibugi and Iammarino, 1999; Tyler and Steensma, 1995; Yamin and Otto, 2004). When R\&D collaboration is concerned, the focus is on research and development activities to which the collaborating partners contribute primarily technological and/or scientific knowledge and where the aim is to develop technical knowledge, products or processes (cf. e.g. Archibugi and Pianta, 1996; Archibugi and Pietrobelli, 2003; Lucena, 2005; Nummela, 2003). ${ }^{6}$

\footnotetext{
${ }^{5}$ According to some researchers, collaboration between domestic MNC units and foreign subsidiaries can be considered less international than collaboration involving only foreign units. This distinction is, however, not that relevant in this study due to our project-level focus. Moreover, it can be argued that ABB has multiple home countries (Bergek and Berggren, 2004), which makes it difficult to disentangle what is 'home' and what is 'foreign'.

${ }^{6}$ The concept of 'technological collaboration' usually includes a much broader range of activities in addition to R\&D , for example workshops and meetings, researcher exchanges and fellowships and
} 
Within this definition, we find three main areas of discussion in the literature when it comes to defining what characterizes 'real' collaboration: (1) the unit of analysis, (2) the degree of interdependence between the partners and (3) the degree of interaction between the partners. Although these issues are somewhat interrelated, we will discuss each in turn.

\section{Unit of analysis}

With regards to the unit of analysis, we can for example choose to focus on company, subunit/research group or individual (Katz and Martin, 1997; Smith et al., 1995). Whereas some researchers consider the mere presence of multiple inventors to be a strong enough indicator of collaboration (e.g. Ma and Lee, 2008), most of the literature on international R\&D collaboration seems to associate the concept of 'collaboration' with at least some degree of organizational separation between the inventors in a project team, i.e. in this context, inventors have to work in different subunits or companies for a project to be considered 'collaboration'.

\section{Degree of interdependence between partners}

The available organizational modes of inter-organizational collaborative activity range from total externalization and independence between the partners (i.e. arm's-length market transactions) to complete internationalization and interdependency (i.e. collaboration with a wholly owned subsidiaries) (e.g. Chiesa and Mancini, 1998; Hagedoorn, 1990, 1993; Narula and Hagedoorn, 1999) (see Figure 1). In-between these extremes there are different types of equity and non-equity agreements (e.g. joint ventures, joint $R \& D$ agreements/alliances, $R \& D$ contracts and licensing) between a firm and vertical partners (i.e. customers and suppliers), horizontal partners (i.e. firms in the same industry and consultants) or academic and other scientific partners (cf., e.g., Chiesa and Manzini, 1998; Frenken et al., 2005; Fritsch and Lukas, 2001; Hagedoorn et al., 2000; Lööf, 2009; Medcof, 1997; Smith et al., 1995).

INSERT FIGURE 1 (Modes of inter-organizational collaborative activity) HERE.

informal exchange of technical knowledge (cf. e.g. Georghiou, 1998; Harabi, 2002; Tyler and Steensma, 1995). 
A first difference of opinion concerns the upper boundary of interdependence, i.e. how interdependent can two partners be and still be considered organizationally separated? In particular, researchers disagree whether $R \& D$ co-practice (i.e. joint technical activities between different sub-units of an MNC, see Frost and Zhou (2005)), should be considered collaboration or not. In the categorization of globalization of innovation by Archibugi and colleagues described previously, a clear distinction is made between on the one hand international generation of technology within MNCs and on the other hand collaboration between different firms. This distinction is made explicitly or implicitly in most of the reviewed literature. However, according to Guellec and van Pottelsberghe de la Potterie (2001, p. 1256), “collaboration between researchers can take place either within a multinational corporation (research facilities in several countries), or through a research joint venture between several firms.” Similarly, Lööf (2009) include “within the group” collaboration among his four categories of collaboration, Medcof (1997) discusses collaboration between different MNC units and Yamin and Otto (2004) define the somewhat broader concept of 'collaborative knowledge sharing' as the knowledge flows or knowledge exchange occurring when inventors from different institutions, or different units within the same firm, are engaged in joint research. In some case-study based studies, Boutellier et al. (1998) study transnational cooperation through dispersed project development teams within IBM and Gassman and von Zedtwitz (2003, p. 243) study “inter-unit R\&D collaboration” focusing on virtual R\&D teams in cross-border innovation projects.

From an ownership perspective, the former perspective might seem most relevant, since in the case of inter-subsidiary collaboration one and the same parent company will have the overall rights to the results. In addition, the knowledge-based view of the firm emphasizes the importance of company boundaries within which a set of joint higherorder principles establish how knowledge and innovation is transferred between individuals and groups (cf. Kogut and Zander, 1992). It should, thus, be much easier to cooperate and communicate within a MNC network than with external partners.

However, MNC differ in terms of the level of integration of their subsidiaries (Almeida and Phene, 2004). As a consequence, collaboration with another unit within the same MNC can be as challenging as inter-firm collaboration, even under the umbrella of joint 
ownership. Inter-subsidiary projects in diversified and duplicated MNC networks can be associated with large technological and political integration challenges (Berggren, 1999), due to, for example, geographic and cultural distance or heterogeneous strategies, incentives and capabilities (Frost and Zhou, 2005; see also Medcof, 1997). Due to the difficulties of handling these and other challenges, similar levels of cooperation can actually be achieved through alliances between independent firms as between separate units of the same company (Almeida et al., 2002).

In line with the latter line of argument, we believe that it is justified to include both inter-firm and inter-subsidiary interaction in the concept of collaboration. However, since it is clear that many researchers would not agree with this definition, we will make a clear distinction between these two types in the empirical analysis.

A second difference of opinion related to the interdependence of the partners concerns the lower boundary of interaction, i.e. how independent can two partners be and still be included in the concept of collaboration? With regards to this question, most researchers agree that external transactions should not be included in the concept of collaboration. There is more disagreement when it comes to the intermediary modes, i.e. agreements of various types. A few researchers only include some equity agreements (e.g. joint ventures) in their definition of collaboration (cf. Archibugi and Pietrobelli, 2003), whereas most include all equity agreements and some non-equity agreements. The main divider here is the category of R\&D contracts, i.e. when one firm contracts another firm to perform a particular research project without participating itself in the actual research activities (cf. Robertson and Gatignon, 1998). Some researchers include these agreements in their definition of R\&D collaboration (e.g. Harabi, 2002; Narula and Hagedoorn, 1998; Sakakibara, 1997), whereas other explicitly exclude them (e.g. Czarnitzki et al., 2004; Tether, 2002). The main issue seems to be the division of labour between partners, which is generally considered an important aspect of collaboration (cf. Georghiou, 1998; Grant, 1996); to many researchers, collaboration implies active participation by all involved partners. A minimum prerequisite is that all participators make real investments and "pool” their resources in order to undertake joint R\&D activities (Hagedoorn et al., 2000; Nummela, 2003; Yamin and Otto, 2004). In the case of R\&D contracts, it can be argued that there is no division of labour since one firm 
performs all $R \& D$. On the other hand, the level of participation of the buyer may range from a pure market transaction based on overall specifications (in which case it would be similar to the totally externalized mode) to a closer relationship where specifications are discussed and altered in an interactive process and the buyer in this process makes a substantial contribution to the R\&D project. In order to capture the latter type of contract, we will include $R \& D$ contracts as a sub-category of $R \& D$ collaboration, but clearly mark them as a separate category alongside traditional 'joint' R\&D activities involving more clear division of labour between partners.

\section{Degree of interaction between the partners}

R\&D collaboration can vary significantly in scope, duration and the level of interaction between partners (Frost and Zhou, 2005). The degree of interaction is to a large extent determined by the organization of the $R \& D$ project as such, i.e. if the project is divided into more or less modular parts that are assigned to different partners or if activities are integrated (cf. Gerwin and Ferris, 2004). ${ }^{7}$ We can, thus, make a distinction between separate work and integrated work, where the latter involves closer interaction between collaboration partners than the former (cf. also Caryannis and Laget, 2004; Georghiou, 1998). This corresponds largely to the distinction between 'co-operation' and 'collaboration' sometimes seen in the literature, where the former refers to sharing or dividing work into independent subtasks and the latter to collective work in terms of synchronous activity (cf. Dillenbourg et al., 1995; Roschelle and Teasley, 1995). ${ }^{8}$

\subsection{Summary and scheme of analysis}

The scheme of analysis is summarized in Figure 2. The first step of the analysis involves determining whether each patent reflects international activity or not. In line with the discussion in Section 2.1, the category 'international' will include patents that are the result of R\&D activities performed by multiple inventors normally working in organizational units located in different countries. We will also discuss to what extent

\footnotetext{
${ }^{7}$ The choice between these options can be influenced by a large number of different contingencies (cf. Gerwin and Ferris, 2004), not least the task at hand; whereas some tasks can be managed through relatively simple mechanisms such as rules and directives, others have to be performed in an integrated fashion in close teams (Grant, 1996).

${ }^{8}$ Cf. the concept of "authentic" global generation of innovation used by Archibugi and Pietrobelli (2003). There are also some more elaborate models that include other categories than these two (cf. Gajda, 1998). For the purpose of this paper, however, we consider this distinction to be detailed enough.
} 
these patents can be considered 'global', i.e. involve inventors from at least two different continents.

Steps 2-4 involve determining whether the international patents are the result of collaboration or not. According to the literature reviewed in section 2.2, R\&D activities have to involve people from two or more organizational units, either subsidiaries of a MNC or different firms in order to qualify as collaboration. In line with this, and to reflect the difference of opinion in literature with regards to R\&D co-practice within MNCs, Step 2 will distinguish between three categories: (1) intra-organizational interaction (which is not considered to be collaboration), (2) intra-subsidiary collaboration (i.e. within an MNC) and (3) inter-firm collaboration (in which we also include collaboration between firms and other types of organizations). After Step 2 we will, thus, have identified all patents that represent international R\&D collaboration in its broadest sense.

In Step 3, we will proceed with both inter-subsidiary and inter-firm patents and divide these into two categories: (1) R\&D contract and (2) joint $R \& D$, in order to reflect the difference of opinion in literature with regards to whether $R \& D$ contracts should be considered collaboration or not.

Finally, in Step 4, the category 'joint R\&D' will be further sub-divided into two categories: (1) separate work and (2) integrated work, where the latter corresponds to one of the strictest definitions of international R\&D collaboration found in literature.

INSERT FIGURE 2 (Scheme of analysis) HERE

\section{Case selection and data collection}

\subsection{Overall study design}

The questions raised in this paper require in-depth knowledge about where the $R \& D$ activities underlying a number of cross-country patents took place, about the partners involved in the activities and about the nature of the interaction between the partners. Such knowledge can only be acquired through a qualitative research approach, primarily based on interviews with the involved inventors. 
In order to fully answer the question of whether cross-country patens are a relevant indicator of international R\&D collaboration, interviews would have to be conducted with a large number of inventors from different companies and industries. We have, however, chosen another approach: a case study design. Although this limits our possibilities to generalize from our findings, there are two main reasons why we consider it appropriate. First, it only takes one "critical” case (Patton, 2002) to question the relevance of an indicator. A critical case is a case that can make a point quite dramatically. Such a case could be one for which we can say that “if it doesn't happen there, it won’t happen anywhere” (Patton, 2002, p. 336). If we can show that even in a case in which we know there to be more international R\&D and interaction than in the average firm, cross-country patents are not a good indicator of international $R \& D$ collaboration, then this will cast severe doubts on the relevance of the indicator also for other cases (although it, of course, does not strictly prove that the indicator is irrelevant in all cases). Thus, even though single-case studies cannot be used for generalization in the strict sense, critical cases can allow “logical generalization” (Patton, 2002). For full generalization to all possible cases, complementary studies of other cases are of course needed. In that sense, this study could be seen as the first step of a sequence of replications, as in the method advocated by Eisenhardt (1989) for theory building from case studies.

Second, a more pragmatic reason for using a single-case study is related to data collection. In a study such as this, access to data is a major problem. Although inventor names are readily available from patent documents, finding inventors current addresses and contact details is far from easy (as will be discussed further below). Limiting ourselves to one case that we were familiar with was simply necessary in order to get a large enough number of interviews within the time and resource frames available to us.

\subsection{Case description}

The case used in this study is ABB, a Swiss-Swedish multinational corporation in the electro-technology industry. Although it was chosen partly because it was convenient, as we had access to the company's patents and also had established contacts in the company, the main reason we chose this company was that it could be considered a critical case, as defined above. ABB has been described as "one of the first truly 
transnational firms” (Katz, 1999, p. 120) and as one of the pioneers of R\&D internationalization (Gassman and von Zedtwitz, 1998). It is considered to have a relatively “strong international orientation” (Meyer-Krahmer and Reger, 1999, p. 755). ABB has also been presented as a role model for transnational organization and global innovation (cf. Bartlett and Ghoshal, 1998). Its R\&D network is “dispersed, duplicated and diversified” (Zander, 1999, p. 208), yet integrated (Gassman and von Zedtwitz, 1998), perhaps as a consequence of a management focus on cross-unit integration and cooperation between companies and countries (Ghoshal and Bartlett, 1998). In addition, $\mathrm{ABB}$ was the leading company in terms of number of strategic technology partnerships in the heavy electrical equipment industry (Hagedoorn, 1995) and also played a leading role in strategic technology cooperation in the field of new materials technologies (Hagedoorn and Schakenraad, 1991) in the late 1980s.

It could, thus, be considered an 'extreme' case in terms of both internationalization and collaboration. It is also extreme in terms of its number of cross-country patents in comparison to other companies in the same industry; the share of cross-country patents in ABB's total stock of patents in a selected number of patent classes in the period of 1996-2000 was $15.6 \%$, which could be compared with a share of $4 \%$ for General Electric (Bergek and Berggren, 2004). ABB, thus, seems to be a case which gives a particularly strong impression that there is indeed a relationship between cross-country patenting and international R\&D collaboration. If we can show that this is not the case, this would enable logical generalization to other, less extreme cases, according to the previous discussion.

\subsection{Data collection}

The empirical basis of this paper is a database containing all patents granted to ABB between 1986 and 2000 by the US Patent Office (USPTO). ${ }^{9}$ The USPTO database was used for two main reasons: First, from our previous work (Bergek and Berggren, 2004; Bergek et al., 2008, 2009) we know that ABB patents almost all of its inventions in the US. Second, most previous patent-based studies of R\&D internationalization use USPTO data. Using them also in this study, thus adds comparability to previous

\footnotetext{
${ }^{9}$ This database was compiled for an earlier study (see Bergek and Berggren, 2004).
} 
research. However, a drawback of the USPTO database is that inventor addresses are updated when the application is granted. The country of residence is, thus, the country in which the inventor lived at the date of patent issue rather than at the date of application. This can result in "false" cross-country patents due to inventor movement. In order to estimate the size of this problem, we searched the European Patent Office (EPO) database for equivalents to the patents in our sample and checked the inventors' addresses at the date of application. Of the seven patents that had an EPO equivalent (including PCT applications), five listed the same country of residence also on the application date. We therefore do not consider this issue to be a major problem in our study.

In total, 367 patents of 3,410 patents in our database are cross-country patents (approximately $11 \%$ ). Of these, we started with a selection of all patents that listed at least one Swedish inventor, 72 in total, since we assumed that it would be much more difficult for us to try to locate foreign inventors than Swedish. Thus, we have investigated about one fifth of the cross-country patents in the database.

We used USPTO patent records, which state the name and town of residence of each inventor at the date of patent issue, as a starting point and then tried to find the current whereabouts of the inventors. Inventors still working for ABB were of course quite easy to find, but these were in minority; many of the inventors have left the company quite a long time ago and often without leaving a forwarding address. On-line telephone directories were helpful to the extent that inventors had non-common names and had stayed in the same location since the patent issue date, which was not always the case, especially when the patent in question was issued some years ago. Inventors were in some cases able to help us locate other inventors. We also managed to find some people through general searches on the Internet. In total, we were able to find the Swedish inventors of 53 patents ( $74 \%$ of the cross-country patents in our sample). ${ }^{10}$ These inventors were contacted and interviewed in a semi-structured way.

We asked the interviewees about the other inventors, where they were located during the project, which role each inventor played and how the work was organized. We also

\footnotetext{
${ }^{10}$ Some of these had more than one patent.
} 
asked them to estimate each inventor's contribution to the patent in percent. In general, interviewees were open and provided detailed answers about the invention, the other inventors and the project, although some of them were initially hesitant to provide the type of information requested, referring to confidentiality reasons. When possible, we double-checked the answers with other co-inventors. It should be noted, however, that it was very difficult to get second opinions from non-Swedish co-inventors since they were either difficult to find or reluctant to discuss the patents since they were not sure that ABB would approve. The large difficulties involved in tracing foreign inventors and in convincing them to speak to us - have forced us to delimit the study to Swedish inventors. It is difficult to estimate the extent to which this has influenced our results, but we will come back to this issue later in the paper.

\subsection{The assignment of cross-country patents to countries}

As stated in Section 2, the analysis will include a more detailed investigation of the geographic dispersion of the activities underlying ABB's cross-country patens.

However, the 'location’ of a patent can be an ambiguous construct (Jaffe et al., 1993) and in previous research a number of different principles have been used to assign patents to countries. According to Grupp and Schmoch (1999), the three most common principles are: assignment by priority country (i.e. the country where the first application was filed), assignment by assignee country (i.e. the country of residence of the applicant or of the MNC's headquarters), and assignment by inventor country (i.e. the country or resident of the inventor(s)).

Since this paper deals with patents with inventors from different countries, assignment by inventor country seems most relevant in this context. This is also the most widely used principle (OECD, 2004). It presumably indicates the location of the technological or inventive activity underlying the patent (Cantwell and Piscitello, 2000; Le Bas and Sierra, 2002; Patel and Vega, 1999; Zander, 1999).

However, it is far from clear how cross-country patents should be dealt with within this principle; the fact that they have multiple inventors from different countries complicates 
their assignment to countries or regions (Jaffe et al., 1993), and a number of different assignment principles are currently in use (see Table 1$).{ }^{11}$

INSERT TABLE 1 (Principles for assignment ...) HERE

Assigning patents by to the country of residence of the first-named inventor seems to be the most common choice (Archambault, 2002). This principle has been used, e.g., in the official statistics of the USPTO (Grupp and Schmoch, 1999) and by well-known researchers such as Pari Patel and John Cantwell. There seem to be two main arguments in favour of this principle. First, some claim that the first-named inventor is the 'primary' or 'priority' inventor, i.e. the most important contributor to the patent (cf. Stolpe, 2002). Second, others claim that the country of residence of the first-named inventor generally reflects the country of invention (cf. Cantwell and Kosmopoulou, 2001; Trajtenberg, 2001). Assignment by multiple counting, where patents are fully attributed to every relevant country, seems to be used primarily in studies of the inventive activity of particular countries or regions (cf. Tijssen, 2001). It is also sometimes used when cross-country patents are used as an indicator of collaboration (cf. Guellec and van Pottelsberghe de la Potterie, 2001; Yamin and Mäkeläinen, 2002). The underlying argument seems to be that this principle better reflects the national basis of patents (Grupp and Schmoch, 1999). ${ }^{12}$ In fractional counting, each inventor and the countries he/she represents is attributed an equal part of the patent. ${ }^{13}$ This principle is advocated by EUROSTAT (Grupp and Schmoch, 1999) and has been used by, e.g. Bergek and Berggren (2004), Stolpe (2002) and Criscuolo et al. (2005). Underlying this assignment principle is the basic assumption that all inventors contribute equally to a patent. ${ }^{14}$ Finally, in some studies patents are assigned according to a majority counting principle, i.e. the patent is assigned to the country from which most of the inventors come (cf. Jaffe et al., 1993).

\footnotetext{
${ }^{11}$ More broadly, the residence of the inventors "denotes ... the historical and cultural background of the inventors, their education system, tax and other policy specificities” (Grupp and Schmoch, 1999, p. 381).

${ }^{12}$ It is also consistent with accepted practice in Scientometrics (Archambault, 2002).

${ }^{13}$ I.e. if there are $p$ inventors from one country and $q$ inventors from another country, the first country is attributed $p /(p+q)$ of the patent, and the other country $q /(p+q)$.

${ }^{14}$ Of course, and as has been discussed above, this is not always the case. Archambault draws an interesting parallel to bibliometrics, arguing that fractional counting would imply "reopening the debate on the fractioning of authorship, only in this case, it would be about inventorship" (Archambault, 2002, p. 23).
} 
Obviously, these four principles rest on different assumptions and it is far from evident which principle is to be preferred over the others. We will therefore apply all four principles and also add a fifth one for comparison: assignment by inventors (based on information gained in the interviews). As mentioned above, we asked the inventors to describe the division of labour in the R\&D project underlying each cross-country patent. We used this information to assign patents to countries. Since some interviewees found it difficult to give a percentage for each inventor, we adopted the following principles for those patents: Projects described as joint projects (with equal contribution of all partners) were distributed evenly between the inventors (as in the 'fractional counting' principle). Contract research patents were allocated in their entirety to the party conducting the $R \& D$ since these projects were not characterized by close buyer-supplier interaction according to the interviewees. For projects in which one partner had done the majority of the work and another had contributed in a smaller way (for example by giving advice), we allocated a standard $10 \%$ of the patent to the minority contributor (although in most cases the contribution seems to have been much smaller). One weakness of this self-reporting methodology is that inventors may overestimate their own contribution to the patents. Combined with the delimitation to Swedish inventors, this could result in an overestimation of the Swedish share of the patents. However, interviewees rather tended to de-emphasize their own contribution and put other inventors before themselves in importance.

\section{Empirical analysis: The case of ABB}

\subsection{Introduction}

In this section, we will use the analytical scheme developed in the previous section to categorize those of ABB's cross-country patents for which we have been able to locate and contact at least one of the listed inventors (see Section 3). We apply the framework step-by-step as described above and discuss the considerations we have made and the result in terms of how well the activities underlying ABB's patents correspond to the different definitions of international R\&D collaboration. The results are summarized in Figure 3.

INSERT FIGURE 3 (Results of the analysis) HERE 


\subsection{To what extent are ABB's cross-country patents international?}

Table 2 shows the country of residence of all inventors listed on the 53 patents in our dataset. Of these, 33 patents (62\% of the investigated patents) are unambiguously international - there is no doubt that the collaborating inventors were either located in different countries during the $\mathrm{R} \& \mathrm{D}$ project in question or were co-located only for a limited part of the project, while normally working at different locations.

Nine patents (17\% of the investigated patents) represent cases in which one of the inventors moved to another country after the R\&D project had ended. For some reason, the inventor's new country of residence was then listed on the patent. (As mentioned in Section 3, this can to some extent be a result of the design of the USPTO system.) All inventors were, thus, resident in the same country and employed by the same organization when the R\&D was conducted and we, therefore, do not consider these patents to be international. For example, one of our patents lists two inventors from Sweden and one from the US, but the 'foreign' inventor told us that the three inventors, in fact, all lived and worked in Sweden during the R\&D project. After the application was filed with the USPTO, he moved to the US and stayed there for one year. During this year, the patent was issued and the US was stated as his country of residence. In another case, a patent that appeared to be shared between Sweden and Norway was the result of R\&D conducted in Sweden by two people living and working in Sweden; the “Norwegian” only moved to Norway after his retirement (some years after the project ended).

In 11 of the cases (21\% of the investigated patents), patents are difficult to categorize. In these cases, inventors were temporarily assigned to a foreign MNC subunit for another purpose than the R\&D project that resulted in the patent in question, worked there for some time and then moved back to their country of origin before the patent was approved. The question with respect to these patents is how long a person can be “on loan” to one organizational unit without it being considered the inventor's normal place of work. We found very little guidance on this matter in previous literature. However, as we do not want to risk underestimating the international character of ABB's cross-country patents (and thereby over-emphasizing the weakness of the indicator) we categorize these patents as international even though they do not fit 
perfectly into our definition of 'international'. Thus, in total 44 of the cross-country patents (83\%) are considered to be the result of international activities.

INSERT TABLE 2 (Number of people ...) HERE

With regards to the more detailed geographic dispersion of the activities underlying the international patents, we can see from Table 2 that the inventors of ABB's crosscountry patents reside in a very limited number of countries. Although quite a few of the patents list inventors from two continents, these are primarily Europe and North America (the US) and in no case are inventors from more than two continents listed on the same patent.

In order to further investigate the geographic dispersion of the 44 international patents, we can see how the patent portfolio as a whole is distributed between countries. As Figure 4 shows, the different assignment principles produce similar results on an overall level: Sweden and the US are totally dominant with a joint share of 68-75 percent and, similarly, Germany and Switzerland have a quite stable joint share of 14 -18 percent. ${ }^{15}$ These results are consistent with the location of ABB's main sub-units.

INSERT FIGURE 4 (Result of different assignment principles ...) HERE

An interesting observation outside the primary scope of this paper is that the different assignment principles produce quite different results with regards to the minimum and maximum shares assigned to especially the two dominant countries USA and Sweden (see Table 3). The US share ranges between 26 percent ('multiple counting') and 50 percent ('first inventor' and 'majority counting') and the Swedish share ranges between 18 percent ('majority counting') and 45 percent ('multiple counting'). We will come back to this finding in Section 5.2.

INSERT TABLE 3 (Comparison between the results ...) HERE

\footnotetext{
${ }^{15}$ It can perhaps be speculated that Sweden's relatively high share according to the interviews (at least in comparison to the 'first inventor' and 'majority counting' principles) is due to the fact that all interviewees were Swedish. However, the single most important factor explaining this pattern is inventor movement as described above, i.e. patents which list inventors who moved from Sweden to another country (or vice versa) between patent application and issue dates.
} 
To conclude this part of the analysis, the majority of ABB's cross-country patents can be considered international. However, these international patents are distributed between a few, dominant locations (US and Sweden) complemented by a few other European locations. They, thus, show very little sign of being truly 'global' as defined in previous research.

\subsection{To what extent are ABB's cross-country patents the result of $R \& D$ collaboration?}

According to our scheme of analysis, the first step of this analysis involves dividing the patents into the three categories of intra-organizational interaction, inter-subsidiary collaboration and inter-firm collaboration. Twelve of the international patents (23\% of the investigated patents) are the result of intra-organizational interaction. These include primarily the ambiguous patents described above, where inventors were employed by the same organizational unit. The remaining 32 patents $(60 \%$ of the investigated patents) fulfil the first collaboration criteria of being either inter-subsidiary or inter-firm patents and thereby represent international $R \& D$ collaboration in its broadest sense. In 24 of these cases (45\% of the investigated patents), inventors were employed by different organizational units within a multinational company and in 8 cases $(15 \%$ of the investigated patents), they were employed by different firms or other types of organizations. Inter-firm patents are the result of collaboration projects between $A B B$ and competitors (3 patents), suppliers (2 patent), consultant firms (1 patent) and universities (3 patents).

The second step of the collaboration analysis involves categorizing the inter-subsidiary and inter-firm patents as the result of either joint R\&D or R\&D contracts. Three of the international collaboration patents (6\% of the investigated patents) are the result of $R \& D$ contracts, i.e. projects in which one or more inventors in one company performed R\&D on behalf of another company or company unit in a different country. Those listed on the patents are, in addition to the person(s) performing the R\&D activities, usually the contact person at the receiving firm (e.g. the person responsible for ordering the R\&D). For example, in one project ABB collaborated with a subcontractor for the purpose of improving an input material supplied by the subcontractor. ABB asked the subcontractor to develop the characteristics of the material further, provided 
specifications for the development and participated in project reviews and in the writing of the patent application. In this case, the contribution of ABB was quite large.

18 patents (34\% of the investigated patents) are the result of joint $R \& D$ projects in which all parties participated actively in the $R \& D$ process. One example is a project including one Swedish inventor and four Swiss inventors. The project leader was localized in Switzerland, and the necessary expertise for implementing the project was sourced from different locations. The R\&D was performed in each inventor's home country. The project lasted for three years, and the members met continuously during this time, both in Sweden and in Switzerland, and communicated via telephone and email in-between meetings. Another example is a patent with one Swedish and three German inventors. The Swedish inventor was project leader and all inventors were engineers that contributed to the patent. The R\&D was performed both in Sweden and in Germany and according to the interviewee they collaborated closely and communicated frequently even if they were working at their home locations. They also met several times in both Sweden and Germany.

The remaining eleven international collaboration patents are the result of other types of activities than these two categories. In Figure 3 we have, therefore, added three empirically identified categories to our framework. ${ }^{16}$ One of these ('R\&D advice') includes $R \& D$ activities other than $R \& D$ contracts and joint $R \& D$, whereas the other two ('patent co-operation' and 'non-R\&D projects') include patents for which the collaboration did not concern R\&D.

The category ' $R \& D$ advice' includes 3 patents ( $6 \%$ of the investigated patents) that are the result of one person from one MNC subsidiary commenting on the R\&D performed by engineers in a foreign subsidiary (the main inventors). For example, in one case a US market director was involved in discussions concerning the progress of a Swedish R\&D project and commented on the R\&D conducted by the Swedish engineers. Although this type of interaction does not correspond perfectly with the notion of R\&D collaboration as described in the literature, it does concern R\&D and the advice from knowledgeable

\footnotetext{
${ }^{16}$ The patents that did not fit into the pre-defined categories were grouped based on the characteristics of the activities underlying the patents, as described by the inventors. We did not apply any strict rules with regards to a minimum number of patents required to form a new category, but rather let each distinct type of activity form its own category. Each category was then labelled to reflect the nature of that activity.
} 
experts can be considered as valuable as the input of customers in $R \& D$ contract projects. We therefore consider this category to reflect the same level of collaboration as the $R \& D$ contract category.

The category 'non-R\&D projects' refers to patents resulting from other activities than $R \& D$ (e.g. maintenance or service). As an example, we may take a patent with two inventors, one US-based and one based in Sweden. For a short period of time, these two engineers performed service assignments together in the US and, based on these experiences, made suggestions for improvements that were later used as a basis for two patent applications. In total, 4 patents ( $8 \%$ of the investigated patents) belong to this category.

Finally, the category 'patent co-operation' refers to collaboration regarding the patent application itself, e.g. when a person from another country is involved in writing the patent application and for that reason is listed as an inventor. For example, two of the patents that list one Swiss and four Swedish inventors are the result of a Swedish R\&D project, which was subjected to a "design review" twice a year by a group of experts. At one occasion, one of the experts suggested a minor change in the original invention in order to broaden the scope of the patent application. In another case, the foreign inventor contributed with suggestions on how the patent application should be formulated in order to exclude as many competitors as possible. In both these cases, the foreign person was included as an inventor along with the original inventors, although s/he did not participate in the actual R\&D. A total number of 4 patents ( $8 \%$ of the investigated patents) are included in this category.

To sum up, of the 32 patents that correspond to the first collaboration criteria, 24 patents (45 percent of the investigated patents) are the result of some kind of $R \& D$ activities (joint $R \& D, R \& D$ contracts or $R \& D$ advice), whereas the other 8 patents are the result of other types of activities, including patent co-operation and non-R\&D projects. Only 18 patents (34\% of the investigated patents) are the result of joint R\&D activities between the partners.

The final step of the collaboration analysis involves categorizing the 18 joint $R \& D$ patents as either separate work or integrated work ('true' collaboration). In five of the 
cases, we were not able get enough information from the interviewees to determine the degree of interaction. Of the remaining 13 cases, none is the result of integrated work. Most commonly, the projects were planned in a joint meeting, after which project members returned to their home countries to perform the $\mathrm{R} \& \mathrm{D}$ in a separate manner. The project teams met perhaps once or twice per year, and most often kept in touch infrequently via e-mail or telephone in between these meetings.

To conclude this part of the analysis, roughly $60 \%$ of the investigated patents are the result of international collaboration in its broadest sense. However, international R\&D activities are actually the source of the patents in less than half of the cases, and only about a third of the patents stem from joint international R\&D projects.

\section{Conclusions and implications for further research}

The purpose of this paper was to examine the cross-country patents of one MNC (ABB) in order to answer the following questions: (1) To what extent are ABB's cross-country patents international and what characterizes the cross-country patents that are not international? (2) To what extent are ABB's international cross-country patents the result of activities corresponding to the notion of $R \& D$ collaboration as described in previous literature and what is the origin of those patents that are not the result of $R \& D$ collaboration? (3) What are the implications of this case study for the relevance of using cross-country patents as an indicator of R\&D collaboration?

With regards to the first of these questions, we can conclude that the main part (83\%) of the investigated cross-country patents are of an international nature, although they can hardly be considered to be global since they are concentrated to a few geographic locations primarily in the US and Europe. It should, however, be noted that this number also includes some ambiguous patents that involve inventors working for some time (although limited) in another country. If these patents are not included, only 60\% of the cross-country patents can be considered international. The patents that we categorized as not international (17\% of the investigated patents) are the result of inventor movement between the patent application and patent issue dates. 
With regards to the second question, 32 of the international patents (60\% of the investigated patents) are the result of collaboration in its broadest sense i.e. involving collaboration between inventors employed either by different subsidiaries of the same MNC or by different firms. Of these, 24 patents (45\% of the investigated patents) are the result of R\&D activities and 18 patents (34\% of the investigated patents) are the result of joint $R \& D$ activities. None of the joint $R \& D$ patents are the result of integrated work ('true' collaboration). If we, in line with some of the literature, exclude intersubsidiary collaboration from further analysis only 2 patents ( $4 \%$ of the investigated patents) can be considered the result of joint $R \& D$.

The patents that are not the result of joint $R \& D$ have their origin in several different sources. Eight patents (16\% of the investigated patents) are the result of non-R\&D projects or patent co-operation, i.e. collaborative activities that do not concern R\&D and therefore are not included in the concept of $R \& D$ collaboration as described in previous literature. Six patents (12\% of the investigated patents) are the result of either $R \& D$ contracts or R\&D advice. Although these are indeed R\&D activities, most of the reviewed literature does not include them in the concept of R\&D collaboration.

Answering the third question requires us to generalize outside the scope of the case study. Considering that ABB can be seen as a critical case with regards to both internationalization and collaboration, we would argue that our results can be used as a basis for discussing the relevance of using cross-country patents as an indicator of R\&D collaboration as described in the literature. The main implications of our study in this respect are the following. First, our findings indicate that cross-country patents are a reasonably good indicator of international activity, especially if labour mobility is considered international in its own right. Second, in spite of the seemingly 'inherent' collaborative nature of these patents, the activities which they are the result of show a number of discrepancies in relation to the definitions of R\&D collaboration found in previous literature:

(a) In the reviewed literature, $R \& D$ collaboration is described as an activity involving two or more relatively independent partners. However, in our study roughly 25 percent of the patents are the result of intra-firm interaction rather than of interaction between independent organizational units. Moreover, 75 percent of the 
patents that can be considered collaboration in a broad sense are the result of inter-subsidiary collaboration rather than of inter-firm collaboration, which implies that a large part of the research community would not consider them to be collaboration either (cf., e.g., Archibugi and Michie, 1995; Fritsch and Lukas, 2001; Hagedoorn, 1990; Nummela, 1999). In fact, only 15 percent of the patents are the result of collaboration between truly independent organizations.

(b) According to the literature, there also has to be a certain amount of interaction and division of labour between the partners for an activity to be considered collaboration (cf. Georghiou, 1998; Grant, 1996). However, in this study only about a third of the patents are the result of joint $R \& D$ projects. The rest are the result of other types of activities, such as R\&D contracts (which were explicitly excluded from the concept of R\&D collaboration in some of the previous literature (cf. Czarnitzki et al., 2004; Tether, 2002)) and R\&D advice (which was hardly mentioned in the literature). It should also be noted that none of the patents corresponds to the strictest definition of R\&D collaboration found in the literature, requiring work to be integrated rather than separated for it to be considered 'true' collaboration (cf. Dillenbourg et al., 1995; Roschelle and Teasley, 1995). Thus, not even within ABB's relatively integrated innovation network (as described in Section 3) do cross-country patents show much sign of the "new innovation processes” and “globally integrated innovation projects” described by Zander (1999).

(c) Finally, 25\% of the cases of inter-subsidiary and inter-firm collaboration in our study did not concern R\&D, but other types of activities such as patent application writing or industrial services. This is perhaps not very surprising considering both that invention is not limited to R\&D activities and that patent laws normally require that all persons that contribute to a patent should be stated as an inventor, regardless of whether the contribution is related to $R \& D$ or to something else. However, this implies that even if we accept cross-country patents as an indicator of collaboration, they are not necessarily a good indicator of $R \& D$ collaboration.

Taken together, these discrepancies indicate that cross-country patents are not a very good indicator of R\&D collaboration as described in previous literature, especially not 
for those who do not consider inter-subsidiary interaction to be collaboration, for those who are only interested in collaboration concerning $R \& D$ and for those who restrict the notion of R\&D collaboration to joint R\&D projects. Other indicators or methods (e.g. innovation surveys) may be a better alternative, especially when stricter definitions of R\&D collaboration are used. Moreover, since this study has illustrated that crosscountry patents may be the result of a number of different types of international activities apart from $R \& D$, it may be useful to separate these different activities from each other. The framework developed in this paper may provide some guidance in this respect.

In addition to these direct implications, this study also has some implications for studies using patents to study R\&D internationalization (or the location of inventive activity) and R\&D collaboration in general.

First, our results challenge the common assumption made in previous literature that inventor addresses say something about the organizational locus of invention (e.g. inventors residing in different countries according to patent documents also work for different organizations (e.g. Etemad and Séguine Dulude, 1987; Frost, 2001; Guellec and van Pottelsberghe de la Potterie, 2001; cf. also Zander, 1999). As our data shows, such patents can very well be the result of intra-firm interaction or inventor movement. This implies that inventor country information should be used with some care for the purpose of identifying the organizational locus of invention.

Second, although this paper is focused on cross-country patents it also gives some reason to doubt the use of patents with multiple inventors as indicators of $R \& D$ collaboration in general. As noted by Stolpe (2002), many if not most patents list more than one inventor, but judging from our findings the co-listing of several inventors does not necessarily mean that they have collaborated to any greater extent (as claimed by e.g. Carayol and Roux (2007) and Ma and Lee (2008)) or even been part of the same R\&D team (as suggested by, e.g., Breschi and Lissoni (2009)). More research is clearly needed to establish the interaction patterns underlying co-patenting.

Third, our analysis of the geographic dispersion of ABB's international cross-country patents resulted in some interesting findings regarding the principles used to assign 
patents with multiple inventors to countries. To our knowledge, no one has previously compared all four established assignment principles with regards to their resulting distribution of patents between countries. ${ }^{17}$ In this paper we made such a comparison and also compared the established principles with an assignment based on information from the inventors (see Figure 4 and Table 3). These two comparisons showed two main things of interest. First, none of the established principles generated substantially different results than the assignment based on interviews. ${ }^{18}$ If we assume that the interview-based assignment reflects the 'true' distribution of inventive activity, this indicates that all of the established principles can very well be used in patent-based studies. Second, in spite of the first finding, the established assignment principles produced quite different results. The distributions of patents between countries generated by the 'fractional counting' and the 'multiple counting' principles differed substantially from those generated by the 'first inventor' and the 'majority counting' principles. ${ }^{19}$ The difference was especially large with respect to the shares assigned to Sweden and the US. With the 'fractional counting' and 'multiple counting' principles, 33/26 percent of the patents were assigned to the US and $42 / 45$ percent to Sweden. The 'first inventor' and 'majority counting' principles generated the opposite result: 23/18 percent to Sweden and 50/50 percent to the US. This indicates that the choice of assignment principle can come to influence the results of studies using patents to study the location of inventive activities. In particular, the differences between the two pairs of principles gives an indication that the possibilities are limited to compare studies using one of the principles from one pair with studies using one of the principles from

\footnotetext{
${ }^{17}$ Grupp and Schmoch (1999) compare different general principles for assigning patents to countries (inventor country, priority country and country of control), but not different principles for assigning cross-country patents. Archambault (2002) compared the 'multiple counting' and 'first inventor' principles, but did not include the other two principles.

${ }^{18}$ Since we have categorical data, a Chi2 test could in principle have been used to test if the different assignment principles produce significantly different results. However, the number of observations for each option is too small for a Chi2 test to be entirely reliable. We will nevertheless report the results of such as test to give an indication of the size of the differences. The Chi2 test did not show any significant difference between the results generated by the interview-based assignment and those produced by the other principles. The same result was achieved if all 53 cross-country patents in our sample were included instead of just the 44 patents that were categorized as international in the previous analysis.

${ }^{19}$ The Chi2 test (see footnote 22 for a discussion about its limitations in this case) showed a statistically significant difference between on the one hand the fractional counting principle and on the other hand the first inventor principle ( $10 \%$ level) and the majority counting principle ( $1 \%$ level). There was also a significant difference ( $1 \%$ level) between the multiple counting principle and both the first inventor and majority counting principles. Basically the same result (although with slightly different significance levels) was achieved if all cross-country patents in our sample were included instead of just the international ones.
} 
the other pair. Our recommendation is, therefore, for researchers to use a combination of principles - one from each pair - in order to control for potential biases.

\section{Acknowledgements}

We are grateful for the valuable comments provided by two anonymous reviewers and by two discussants at the DRUID Tenth Anniversary Summer Conference 2005 on Dynamics of Industry and Innovation: Organizations, Networks and Systems, Copenhagen, June 27-29, 2005.

\section{References}

Acs, Z.J., Anselin, L., Varga, A., 2002. Patents and innovation counts as measures of regional production of new knowledge. Research Policy 31(7), 1069-1085.

Almeida, P., Phene, A., 2004. Subsidiaries and knowledge creation: the influence of the MNC and host country on innovation. Strategic Management Journal 25, 847-864. Almeida, P., Song, J., Grant, R.M., 2002. Are Firms Superior to Alliances and Markets? An Empirical Test of Cross Border Knowledge Building. Organization Science 13(2), 147-161.

Archambault, É., 2002. Methods for using patents in cross-country comparisons. Scientometrics 54(1), 15-30.

Archibugi, D., Coco, A., 2001. The Globalisation of Technology and the European Innovation System. IEEE Working Paper DT09/2001.

Archibugi, D., Coco, A., 2004. International partnerships for knowledge in business and academia. A comparison between Europe and the USA. Technovation 24(7), 517528.

Archibugi, D., Michie, J., 1995. The globalization of technology: a new taxonomy, Cambridge Journal of Economics 19(1), 121-140.

Archibugi, D., Pianta, M., 1996. Measuring technological change through patents and innovation surveys. Technovation 16(9), 451-468.

Archibugi, D., Pietrobelli, C., 2003. The globalization of technology and its implications for developing countries: Windows of opportunity or further burden? Technological Forecasting \& Social Change 70(9), 861-883. 
Bartlett, C., Ghoshal, S., 1998. Managing Across Borders. The Transnational Solution. Harvard Business School Press, Boston

Bergek, A., Berggren, C., 2004. Technological internationalization in the electrotechnical industry: a cross-company comparison of patenting patterns 1986-2000. Research Policy 33(9), 1285-1306.

Bergek, A., Berggren, C., Tell, F., Watson, J., 2008. Technological capabilities and late shakeouts: Industrial dynamics in the advanced gas turbine industry, 1986-2002. Industrial and Corporate Change 17(2), 335-392.

Bergek, A., Tell, F., Berggren, C., 2009. Do technology strategies matter? A comparison of two electrical engineering corporations, 1988-1998. Technology Analysis \& Strategic Management 21(4), 445-470.

Berggren, C., 1999b. Distributed development in a multinational, in: Bélanger, J., Berggren, C., Björkman, T., Köhler,C. (Eds), Being Local Worldwide-ABB and the Challenge of Global Management. Cornell University Press, Ithaca, pp. 233247.

Bottazzi, L., Peri, G., 2003. Innovation and spillovers in regions: Evidence from European patent data. European Economic Review 47(4), 687-710.

Boutellier, R., Gassmann, O., Macho, H., Roux, M., 1998. Management of dispersed product development teams: the role of information technologies. $R \& D$ Management 28(1), 13-25.

Breschi, S., Lissoni, F., 2009. Mobility of skilled workers and co-invention networks: an anatomy of localized knowledge flows. Journal of Economic Geography 9(4), 439-468.

Cantwell, J., Kosmopoulou, E., 2001. Determinants of internationalization of corporate technology. DRUID Working Papers 01-08.

Cantwell, J., Piscitello, L., 2000. Accumulating technological competence: its changing impact on corporate diversification and internationalization. Industrial and Corporate Change 9(1), 21-51.

Cantwell, J., Piscitello, L., 2005. Recent Location of Foreign-owned Research and Development Activities by Large Multinational Corporations in the European Regions: The Role of Spillovers and Externalities. Regional Studies 39(1), 1-16. 
Cantwell, J., Vertova, G., 2004. Historical evolution of technological diversification. Research Policy 33, 511-529.

Carayol, N., Roux, P., 2007. The strategic formation of inter-individual collaboration networks. Evidence from co-invention patterns. Annales d’Économie et de Statistique 87/88, 275-301.

Caryannis, E.G., Laget, P., 2004. Transatlantic innovation infrastructure networks: public-private, EU-US R\&D partnerships. R\&D Management 34(1), 17-31.

Chiesa, V., Manzini, R., 1998. Organizing for technological collaborations: a managerial perspective, R\&D Management 28(3), 199-212.

Cincera, M., van Pottelsberghe de la Potterie, B., Veugelers, R., 2006. Assessing the foreign control of production of technology. The case of a small open economy. Scientometrics 66(3), 493-512.

Contractor, F.J., Lorange, P., 2002. Why Should Firms Cooperate? The Strategy and Economics Basics for Cooperative Ventures, in: Contractor, F.J., Lorange, P. (Eds), Cooperative Strategies in International Business. Joint Ventures and Technology Partnerships between Firms ( $2^{\text {nd }}$ Ed.). Elsevier Science, Oxford, pp. 3-30.

Corrocher, N., Malerba, F., Montobbio, F., 2003. The emergence of new technologies in the ICT field: main actors, geographical distribution and knowledge sources. Working Paper 2003/37, Department of Economics, University of Insubria, Varese.

Criscuolo, P., Narula, R., Verspagen, B., 2005. Role of home and host country innovation systems in R\&D internationalization: a patent citation analysis. Economics of Innovation and New Technology 14(5), 417-433.

Czarnitzki, D., Ebersberger, B., Fier, A., 2004. The Relationship between R\&D Collaboration, Subsidies and Patenting Activity: Empirical Evidence from Finland and Germany, ZEW Discussion Paper No. 04-37, Zentrum für Europäische Wirtschaftsforschung GmbH.

Dachs, B., Schibany, A., 2004. The Internationalisation of Innovative Activities in Austria Measured by Patent Data, fteval newsletter No. 222004. 
Doz, Y.L., 1996. The Evolution of Cooperation in Strategic Alliances: Initial Conditions or Learning Processes, Strategic Management Journal 17 (special issue), 55-83.

Dillenbourg, P., Baker, M., Blaye, A., O’Malley, C., 1995. The Evolution of Research on Collaborative Learning, in: Spada, E., Raiman, P. (Eds.), Learning in Humans and Machine: Towards an interdisciplinary learning science, Elsevier, Oxford, pp. 189-211.

Eaton, J., Kortum, S., 1996. Trade in ideas: Patenting and productivity in the OECD. Journal of International Economics 40, 251-278.

Edler, J., 2004. International research strategies of multinational corporations: A German perspective. Technological Forecasting and Social Change 71(6), 599621.

Ejermo, O., 2003. Patent Diversity as a Predictor of Regional Innovativeness in Sweden. CESPRI Working Paper 2003/140, Bocconi University, Milan.

Etemad, H., Séguin Dulude, L., 1987. Patenting patterns in 25 large multinational enterprises. Technovation 7(1), 1-15.

Frenken, K., Hölzl, W., de Vor, F., 2005. The citation impact of research collaborations: the case of European biotechnology and applied microbiology (1988-2002), Journal of Engineering and Technology Management 22(1-2), 9-30.

Fritsch, M., Lukas, R., 2001. Who cooperates on R\&D? Research Policy 30, 297-312.

Frost, T.S., 2001. The geographic sources of foreign subsidiaries' innovations. Strategic Management Journal 22(2), 101-123.

Frost, T.S., Zhou, C., 2005. R\&D co-practice and 'reverse' knowledge integration in multinational firms. Journal of International Business Studies 36(6), 676-687.

Furman, J.L., Porter, M.E., Stern, S., 2002. The determinants of neational innovative capacity. Research Policy 31(6), 899-933.

Gajda, R., 2004. Utilizing Collaboration Theory to Evaluate Strategic Alliances. American Journal of Evaluation 25(1), 65-77.

Gassmann, O., von Zedtwitz, M., 1998. Organization of industrial R\&D on a global scale. R\&D Management 28(3), 147-161.

Gassmann, O., von Zedtwitz, M., 2003. Trends and determinants of managing virtual R\&D teams. R\&D Management 33(3), 243-262. 
Georghiou, L., 1998. Global cooperation in research. Research Policy 27(6), 611-626.

Gerybadze, A., Reger, G., 1999. Globalization of R\&D: recent changes in the management of innovation in transnational corporations. Research Policy 28(2-3), 251-274.

Grant, R.M., 1996. Toward a knowledge based theory of the firm, Strategic Management Journal 17 (winter special issue), 109-122.

Grupp, H., Schmoch, U., 1999. Patent statistics in the age of globalization: new legal procedures, new analytical methods, new economic interpretation. Research Policy 28(4), 377-396.

Guellec, D., van Pottelsberghe de la Potterie, B., 2001. The internationalization of technology analysed with patent data. Research Policy 30(8), 1253-1266.

Hagedoorn, J., 1990. Organizational modes of inter-firm co-operation and technology transfer. Technovation 10(1), 17-30.

Hagedoorn, J., 1993. Understanding the Rationale of Strategic Technology Partnering: Interorganizational Modes of Cooperation and Sectoral Differences. Strategic Management Journal 14(5), 371-385.

Hagedoorn, J., 1995. Strategic technology partnering during the 1980s: Trends, networks and corporate patterns in non-core technologies. Research Policy 24(2), 207-231.

Hagedoorn, J., Link, A.N., Vonortas, N.S., 2000. Research partnerships. Research Policy 29, 567-586.

Hagedoorn, J., Schakenraad, J., 1991. Inter-firm partnerships for generic technologiesthe case of new materials. Technovation 11(7), 429-444.

Harabi, N., 2002. The impact of vertical R\&D cooperation on firm innovation: an empirical investigation. Economics of Innovation and New Technology 11(2), 93108.

Howells, J., 1990. The internationalization of R\&D and the Development of Global Research Networks. Regional Studies 24(6), 495-512.

Hu, A.G.Z., Jaffe, A.B., 2003. Patent citations and international knowledge flow: the cases of Korea and Taiwan. International Journal of Industrial Organization 21, 849-880. 
Jaffe, A.B., Trajtenberg, M., 1996. Flows of knowledge from universities and federal laboratories: Modeling the flow of patent citations over time and across institutional and geographic boundaries. Proceedings of the National Academy of Science USA 93, 12671-12677.

Jaffe, A.B., Trajtenberg, M., Henderson, R., 1993. Geographic localization of knowledge spillovers as evidenced by patent citations. The Quarterly Journal of Economics 108(3), 577-598.

Katz, J., 1999. The new global leaders. The Academy of Management Executive 13(3), 119-120.

Katz, J.S., Martin, B.R., 1997. What is research collaboration? Research Policy 26, 118.

Kogut, B., Zander, U., 1992. Knowledge of the Firm, Combinative Capabilities, and the Replication of Technology. Organization Science 3(3), 383-397

Kuemmerle, W., 1999. Foreign direct investment in industrial research in the pharmaceutical and electronics industries-results from a survey of multinational firms. Research Policy 28, 179-193.

Le Bas, C., Sierra, C., 2002. 'Location versus home country advantages' in R\&D activities: some further results on multinationals' location strategies. Research Policy 31, 589-609.

Lucena, A., 2005. The production of complementarities among R\&D activities and external collaboration: a knowledge-based view. DRUID Academy Winter 2005 PhD Conference, Aalborg

Lööf, H., 2009. Multinational enterprises and innovation: firm level evidence on spillover via R\&D collaboration. Journal of Evolutionary Economics 19(1), 4171.

Ma, Z., Lee, Y., 2008. Patent application and technological collaboration in inventive activities: 1980-2005. Technovation 28(6), 379-390.

Mariani, M., 2004. What determines technological hits?: Geography versus firm competencies. Research Policy 33(10), 1565-1582.

Medcof, J.W., 1997. A taxonomy of internationally dispersed technology units and its application to management issues. R\&D Management 24(4), 301-318. 
Meyer, M., Bhattacharya, S., 2004. Commonalities and differences between scholarly and technical collaboration. Scientometrics 61(3), 443-456.

Meyer-Krahmer, F., Reger, G., 1999. New perspectives on the innovation strategies of multinational enterprises: lessons for technology policy in Europe. Research Policy 28(7), 751-776.

Narula, R., Hagedoorn, J., 1999. Innovating through strategic alliances: moving towards international partnerships and contractual agreements. Technovation 19(5), 283294.

Narula, R., Zanfei, A., 2003. Globalisation of Innovation: The Role of Multinational Enterprises. DRUID Working Paper 03-15.

Nummela, N., 2003. Looking through a prism—-multiple perspectives to commitment to international R\&D collaboration. Journal of High Technology Management Research 14, 135-148.

OECD (2004): 2004 Compendium of Patent Statistics. Economic Analysis and Statistics Division of the OECD Directorate for Science, Technology and Industry.

Patel, P., 1995. Localised production of technology for global markets. Cambridge Journal of Economics 19(1), 141-153.

Patel, P., 1996. Are Large Firms Internationalising the Generation of Technology? Some New Evidence. IEEE Transactions on Engineering Management 43(1), 4147.

Patel, P., Pavitt, K., 1991. Large firms in the production of the world's technology: an important case of “non-globalization”. Journal of International Business Studies 22(1), 1-21.

Patel, P., Vega, M., 1999. Patterns of internationalization of corporate technology: location vs. home country advantages. Research Policy 28, 145-155.

Patton, M.Q., 2002. Qualitative Research \& Evaluation Methods ( $3^{\text {rd }}$ ed.). Sage Publications, Thousand Oaks.

Robertson, T.S., Gatignon, H., 1998. Technology development mode: a transaction cost conceptualization. Strategic Management Journal 19(6), 515-531.

Roschelle, J., Teasley, S., 1995. The construction of shared knowledge in collaborative problem solving, in: O’Malley, C.E. (Ed.), Computer Supported Collaborative Learning. Springer-Verlag, Heidelberg, pp. 69-97. 
Sakakibara, M., 1997. Heterogeneity of firm capabilities and cooperative research and development: an empirical examination of motives. Strategic management journal 18 (summer special issue), 143-164.

Singh, J., 2008. Distributed R\&D, cross-regional knowledge integration and quality of innovative output. Research Policy 37(1), 77-96.

Smith, K.G., Carroll, S.J., Ashford, S.J., 1995. Intra- and Interorganizational Cooperation: Toward a Research Agenda. The Academy of Management Journal 38(1), 7-23.

Sorenson, O., Fleming, L., 2004. Science and the diffusion of knowledge. Research Policy 33(10), 1615-1634.

Stolpe, M., 2002. Determinants of knowledge diffusion as evidenced in patent data: the case of liquid crystal display technology. Research Policy 31, 1181-1198.

Tether, B.S., 2002. Who co-operates for innovation, and why. An empirical analysis. Research Policy 31, 947-967.

Tijssen, R.J.W., 2001. Global and domestic utilization of industrial relevant science: patent citation analysis of science-technology interactions and knowledge flows. Research Policy 30(1), 35-54.

Trajtenberg, M., 2001. Innovation in Israel 1968-1997: a comparative analysis using patent data. Research Policy 30(3), 363-389.

Tyler, B.B., Steensma, H.K., 1995. Evaluating Technological Collaborative Opportunities: A Cognitive Modeling Perspective. Strategic Management Journal 16 (special issue), 43-70.

Yamin, M., Mäkeläinen, K., 2002. Internationalisation of innovative activities in Finnish multinational enterprises. Paper presented at the The Annual conference of the European International Business Association, Athens, Greece, December 2002.

Yamin, M., Otto, J., 2004. Patterns of knowledge flows and MNE innovative performance. Journal of International Management 10, 239-258.

Zander, I., 1999. How do you mean 'global'? An empirical investigation of innovation networks in the multinational corporation. Research Policy 28(2-3), 195-213. 
Zander, I., 2002. The formation of international innovation networks in the multinational corporation: an evolutionary perspective. Industrial and Corporate Change 11(2), 327-353. 


\section{Tables}

TABLE 1: Principles for assignment of cross-country patents (by papers using the principle).

\begin{tabular}{lll}
\hline ASSIGNMENT PRINCIPLE & \multicolumn{2}{l}{ PAPERS IN WHICH THE PRINCIPLE IS USED } \\
\hline \multirow{2}{*}{ FIRST-NAMED INVENTOR } & Acz et al. (2002) & Frost (2001) \\
& Bottazzi \& Peri (2003) & Hu \& Jaffe (2003) \\
& Cantwell \& Kosmopoulou (2001) & Patel \& Vega (1999) \\
& Cantwell \& Piscitello (2005) & Singh (2008) \\
& Cantwell \& Vertova (2004) & Sorenson \& Fleming (2004) \\
& Corrocher et al. (2003) & Stolpe (2002) \\
& Ejermo (2003) & Trajtenberg (2001) \\
\hline \multirow{2}{*}{ FRACTIONAL COUNTING } & Bergek \& Berggren (2004) & Dachs \& Schibany (2004) \\
& Criscuolo et al. (2005) & Stolpe (2002) \\
\hline \multirow{2}{*}{ MULTIPLE COUNTING } & Archambault (2002) & Tijssen (2001) \\
& Grupp \& Schmoch (1999) & Yamin \& Mäkeläinen (2002) \\
& Guellec \& van Pottelsberghe de & Yamin \& Mäkeläinen (2004) \\
& la Potterie (2001) & \\
\hline \multirow{2}{*}{ MAJORITY COUNTING } & Jaffe et al (1993) & Mariani (2004) \\
& & \\
\hline \multirow{2}{*}{ NOT SPECIFIED } & Almeida \& Phene (2004) & Le Bas \& Sierra (2002) \\
& Cantwell \& Piscitello (2000) & Patel (1995; 1996) \\
& Eaton \& Kortum (1996) & Patel \& Pavitt (1991) \\
& Edler (2004) & Yamin \& Otto (2004) \\
& Furman et al. (2002) & Zander (1999; 2002) \\
& Jaffe \& Trajtenberg (1996) & \\
\hline
\end{tabular}


TABLE 2: Number of people from different countries stated as inventors per patent.

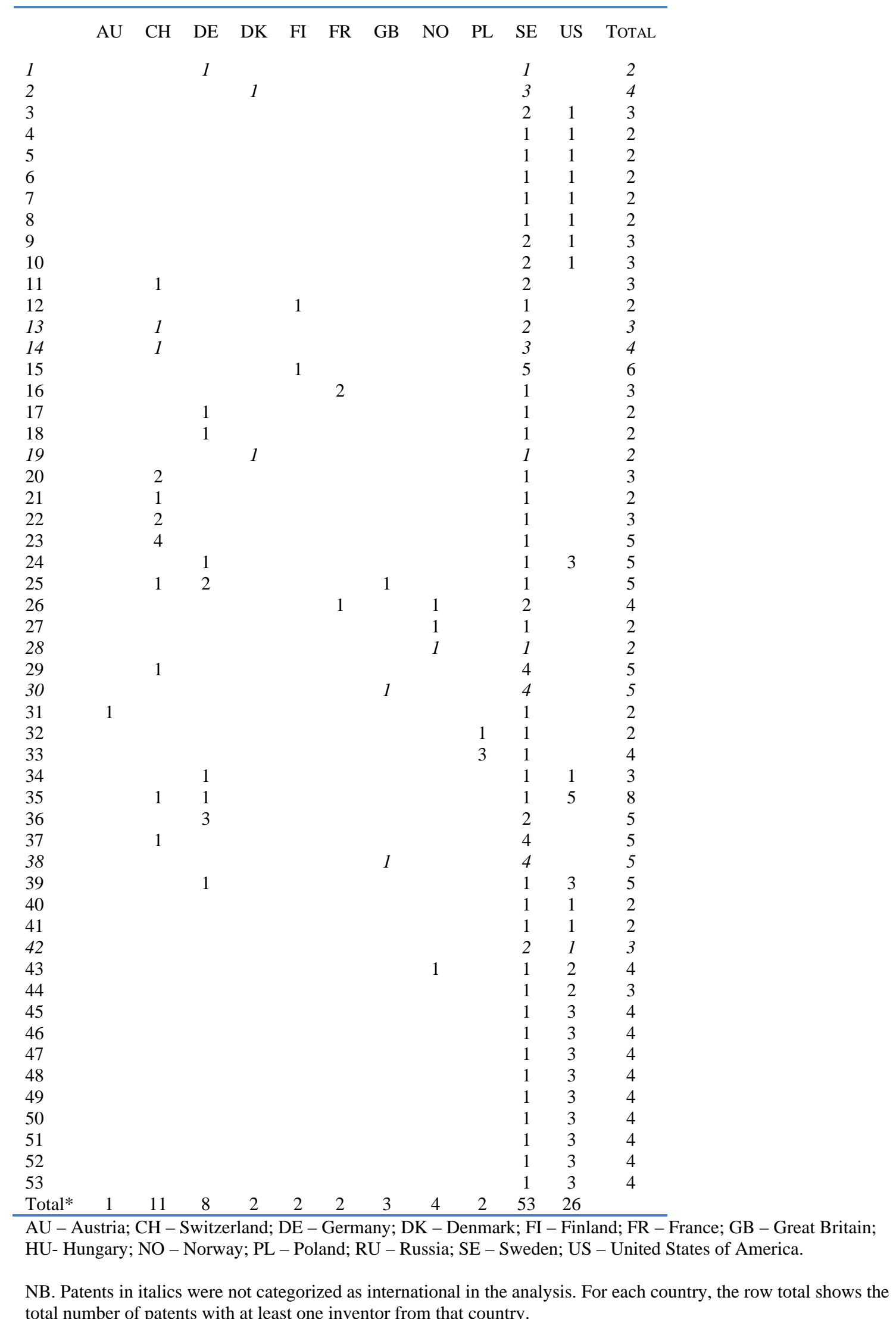
total number of patents with at least one inventor from that country. 
TABLE 3: Comparison between the results of established assignment principles and the location of $R \& D$ activities as described by the inventors.

\begin{tabular}{|c|c|c|c|c|c|}
\hline & $\begin{array}{c}\text { FIRST } \\
\text { INVENTOR }\end{array}$ & $\begin{array}{l}\text { MAJORITY } \\
\text { COUNTING }\end{array}$ & $\begin{array}{c}\text { FRACTIONAL } \\
\text { COUNTING }\end{array}$ & $\begin{array}{l}\text { MULTIPLE } \\
\text { COUNTING }\end{array}$ & INVENTORS \\
\hline Sweden & 10 (23\%) & $8(18 \%)$ & 18 (42\%) & 44 (45\%) & 14 (31\%) \\
\hline USA & 22 (50\%) & 22 (50\%) & 15 (33\%) & 25 (26\%) & 18 (41\%) \\
\hline Switzerland & 4 (9\%) & $4(9 \%)$ & $4(8 \%)$ & $9(9 \%)$ & $4(9 \%)$ \\
\hline Germany & 4 (9\%) & $4(9 \%)$ & $3(6 \%)$ & 8 (8\%) & $2(6 \%)$ \\
\hline \multirow[t]{2}{*}{ Other } & $4(9 \%)$ & $6(14 \%)$ & $5(10 \%)$ & $11(11 \%)$ & $6(13 \%)$ \\
\hline & 44 (100\%) & $44(100 \%)$ & $44(100 \%)$ & $97(100 \%)$ & $44(100 \%)$ \\
\hline
\end{tabular}

\section{Figures $^{20}$}

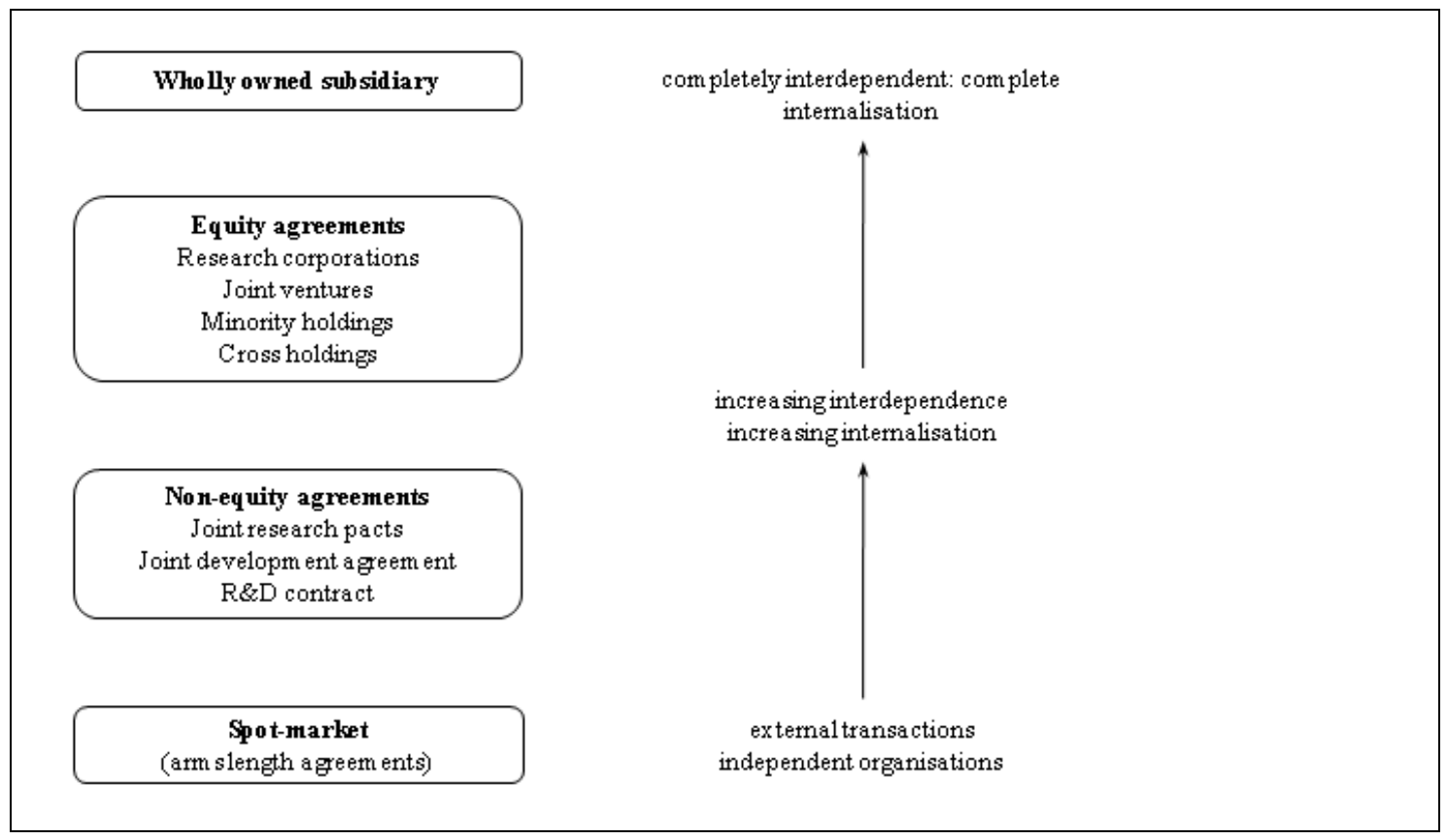

Figure 1: Modes of inter-organizational collaborative activity (Adapted from Narula and Hagedoorn (1999))

${ }^{20}$ Figures (gif-format) are included here only as an illustration. Original files are submitted separately. 


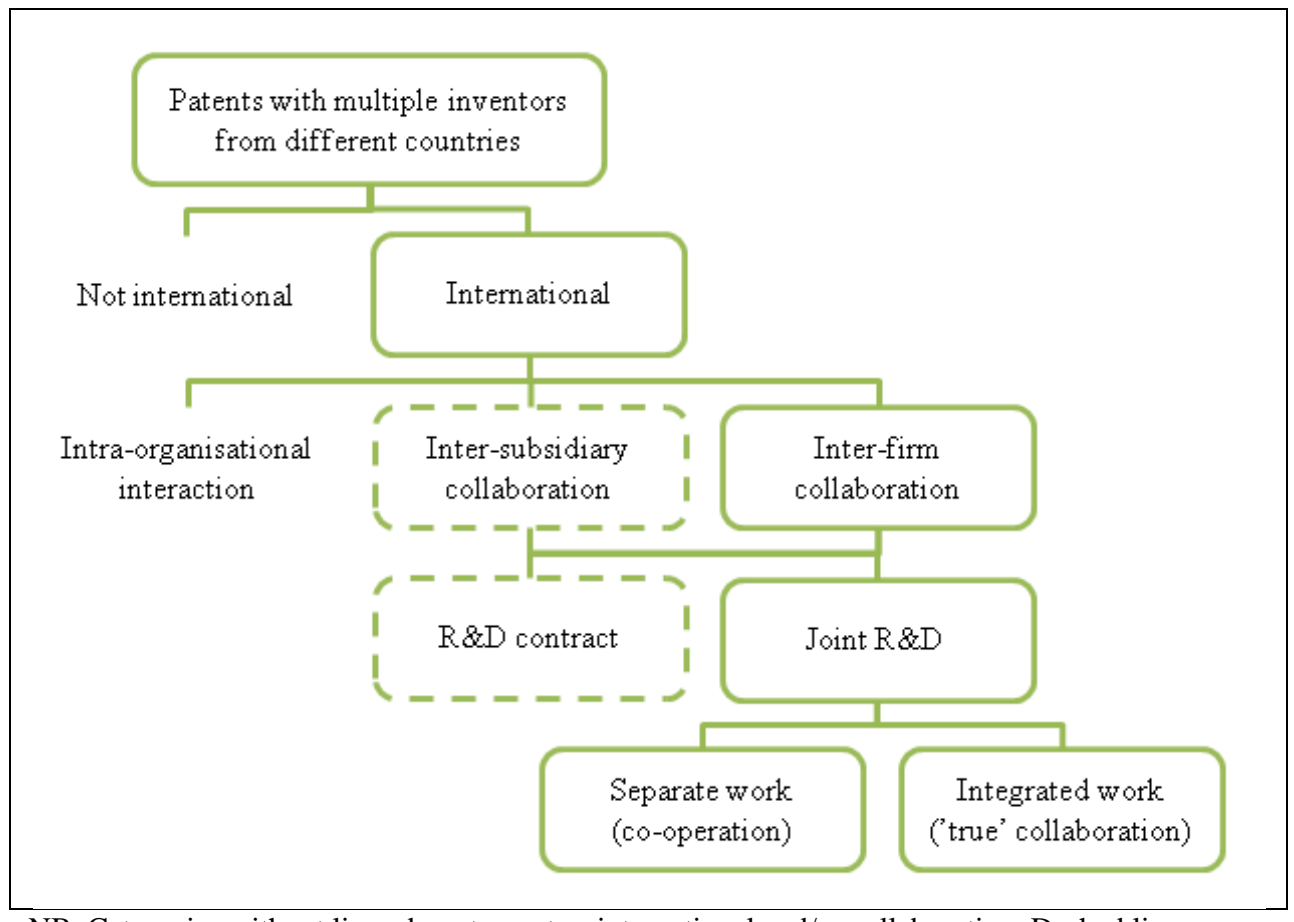

NB. Categories without lines do not count as international and/or collaboration. Dashed lines indicate a difference of opinion in literature with regards to whether the category should be included or not.

Figure 2: Scheme of analysis

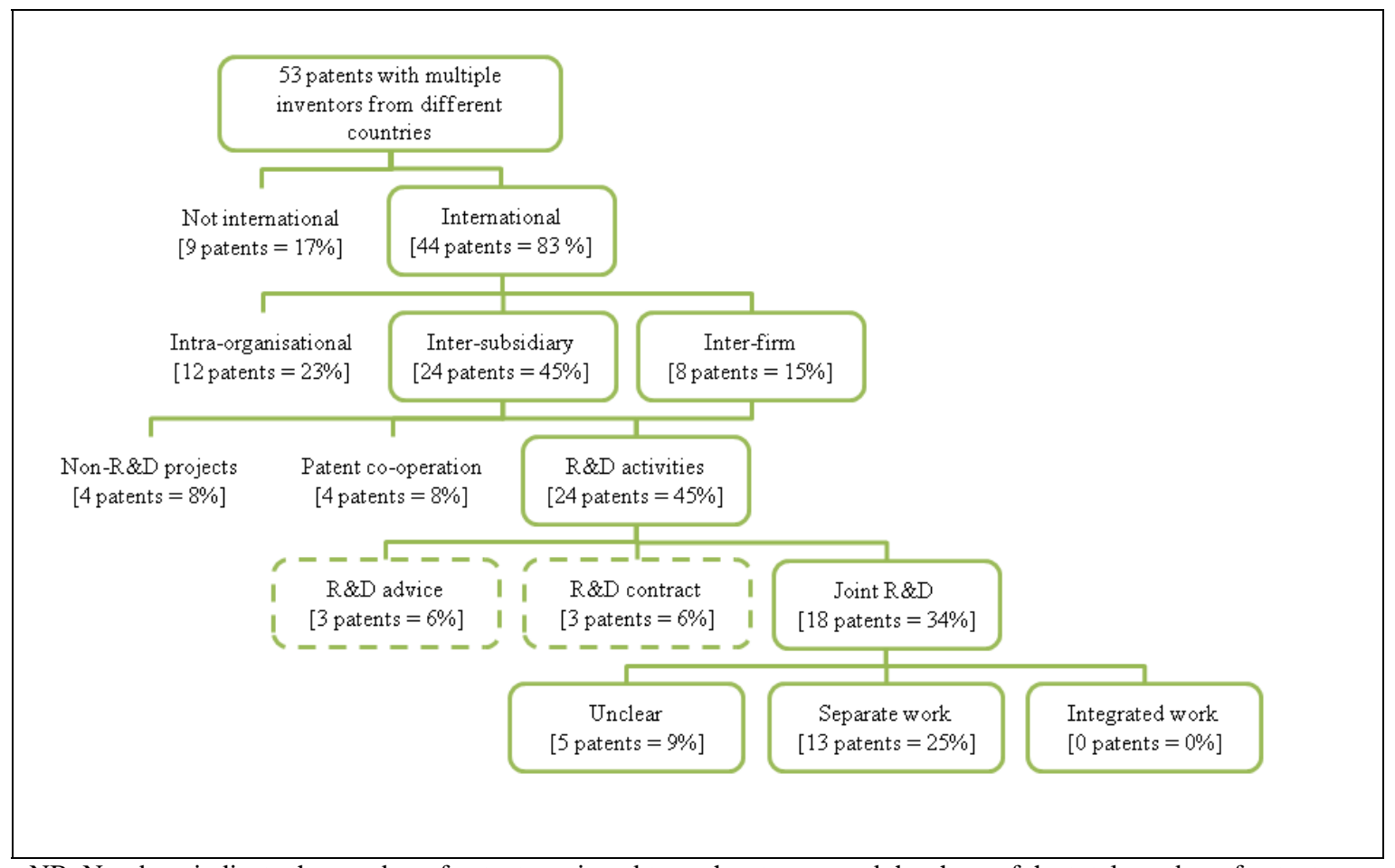

NB. Numbers indicate the number of patents assigned to each category and the share of the total number of patents included in the analysis Categories without lines do not count as international and/or collaboration. Dashed lines indicate a difference of opinion in literature with regards to whether the category should be included or not.

Figure 3: Results of the analysis 


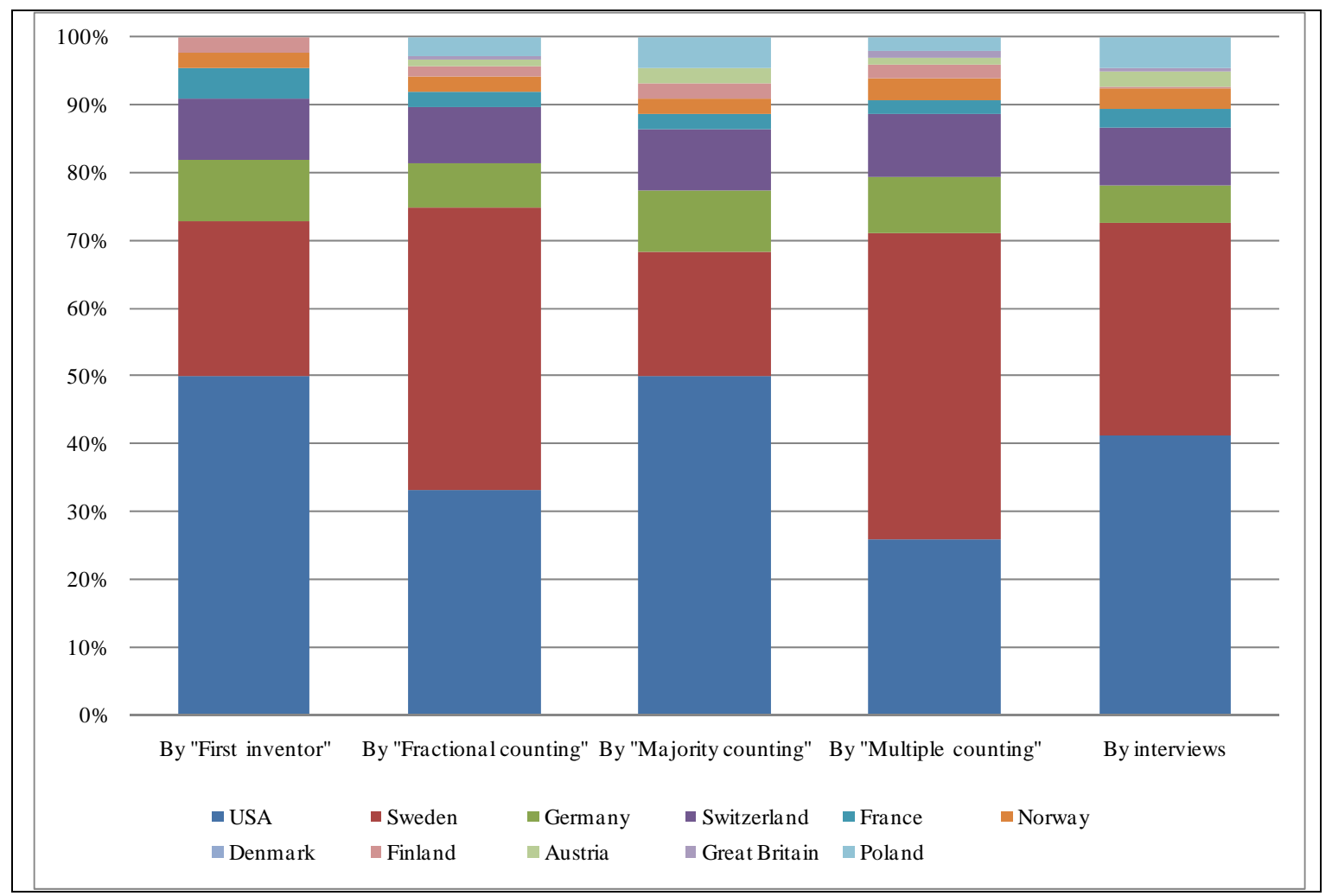

Figure 4: The result of different assignment principles applied to ABB's international cross-country patents. 